\title{
The Law Enforcement of Environmental Law against Illegal Mining
}

\author{
Khoirulika Nur Harinda*), Amin Purnawan**), and Aryani Witasari ${ }^{* * *}$ ) \\ *) Indonesian National Police, Resort Kudus, E-mail: harindaz@gmail.com \\ **) Faculty of Law, Universitas Islam Sultan Agung (UNISSULA) Semarang \\ ${ }^{* * *}$ ) Faculty of Law, Universitas Islam Sultan Agung (UNISSULA) Semarang
}

\begin{abstract}
.
The purpose of this study is to identify and analyze law enforcement against illegal mining in Indonesia. Based on the results of the study, it can be concluded that illegal mining law enforcement is an unlawful act, regulated by Act No. 4 of 2009 concerning Mineral and Coal Mining, the threat of punishment is regulated from Articles 158 to 165. Administrative law enforcement in illegal mining crimes by the authority law enforcement is carried out in a preventive manner. Supervision in law enforcement of mining administration in a limited manner has been regulated as stipulated in the provisions of Article 39, Article 78 and Article 79 concerning Mining Business Permits (IUP) or Special Mining Business Permits (IUPK). The signs contained in the Mining Business Permit (IUP) or Special Mining Business Permit (IUPK), are obligations that must be carried out by the recipient of the Mining Business Permit (IUP) or Special Mining Business Permit (IUPK), and if a violation is committed, the official who issuing the permit has the right to impose sanctions. Based on this suggestion, it is hoped that there will be coordination and integration between relevant agencies, in particular to carry out socialization activities for legal counseling regarding Act No. 4 of 2009.
\end{abstract}

Keywords: Enforcement; Environment; Illegal; Law; Mining.

\section{Introduction}

Article 33 paragraph (3) of the 1945 Constitution of the Republic of Indonesia states that "The land and water and the natural resources contained therein are controlled by the State and used for the greatest prosperity of the people". Based on Article 33 paragraph (3) of the 1945 Constitution of the Republic of Indonesia as mentioned above, the natural resources owned by Indonesia are managed by the state for the welfare of the people. These natural resources are managed and utilized for the welfare of the Indonesian people/people.

The prosperity of the people is the spirit and the ultimate goal of a welfare state that must be realized by the state and government of Indonesia. The mining sector is one of the driving wheels of the economy in Indonesia with various types of excavation based on the classification of minerals.

Mining according to Article 1 paragraph (1) of Act No. 4 of 2009 concerning Mineral and Coal Mining is part or all of the stages of activities in the context of research, management and exploitation of minerals or coal which include general investigations, exploration, feasibility studies, construction, mining, processing and refining, transportation and sales, and post-mining activities.

Mining is required to have a mining business permit, permit or permit is one of the legal instruments of state administration that can be used for law 
enforcement to take legal action in carrying out their duties and authorities. In general, permits enter into state administrative law which applies regulations in concrete terms based on requirements and procedures as stipulated by statutory provisions. $^{1}$

The purpose of a mining business license is to direct (control stress) certain activities (eg building permits), Permits to prevent harm to the environment (environmental permits), desire to protect certain objects, Permits to provide direction by selecting people and activities (permits based on "drank en horecawet" where the management must meet certain conditions).

Mining permits are required for mining entrepreneurs as a requirement before starting a mining business, anyone who has a mining business without a permit must be prosecuted based on the laws and regulations in force in Indonesia. UU no. 4 of 2009 concerning Mineral and Coal Mining began to open new horizons regarding the juridical aspect of mining management from the environmental aspect, while also mentioning the independence of Indonesian mining. From the environmental aspect, the Act began to accommodate several environmental problems.

Mining without a permit or what is commonly called illegal mining is not only detrimental to the state financially, but is often the cause of various problems such as environmental damage, social conflict, crime, inequality in economic value or even encouraging new poverty. The phenomenon of illegal mining in some areas even disturbs and threatens public security and order. ${ }^{2}$

Mining law has a very close relationship with environmental law because every mining business, whether it is related to general mining or oil and gas mining, is required to maintain the continuity of the carrying capacity and capacity of the environment. This is commonly referred to as the preservation of environmental functions. ${ }^{3}$ Permit is an agreement from the government based on laws or government regulations to in certain circumstances deviate from the provisions of the statutory prohibition. Mining problems are not only related to foreign exchange issues, permits as a form of government supervision of mining have an important role in environmental law enforcement.

\section{Research Methods}

This research uses normative or doctrinal legal research. Normative legal research or doctrinal legal research which is also referred to as library research or document study is research carried out or aimed only at examining written

\footnotetext{
${ }^{1}$ Ruth Laksmi Charisma, "Problematika Penegakan Hukum Kegiatan Pertambangan Batuan Ilegal di Kota Samarinda", Jurnal Hukum, Faculty of Law, Universitas Mulawarman, p. 46.

2Dany Andhika Karya Gita, Amin Purnawan, Djauhari, "Kewenangan Kepolisian Dalam Menangani Tindak Pidana Pertambangan (Ilegal Mining) Menurut Undang-Undang Nomor 4 Tahun 2009 (Studi Di Kepolisian Negara Indonesia)”, Jurnal Daulat Hukum Vol. 1. No. 1 March 2018 ISSN: 2614-560X, url: http://jurnal.unissula.ac.id/index.php/RH/issue/view/247

${ }^{3}$ Siti Sundari Rangkuti, 2008, "Perangkat Hukum Lingkungan: Dari Ius Constitutum, Sekali Lagi, Ke Ius Constituendum, disampaikan pada Seminar "Good Governance and Good Environmental Governance", Faculty of Law Universitas Airlangga, Surabaya, p. 5.
} 
regulations or other legal materials. ${ }^{4}$ The specification used is descriptive, which is a study that aims to provide a concrete description or explanation of the state of the object or problem under study without drawing general conclusions. ${ }^{5}$ The data in this study uses a statute approach and a conceptual approach. The collection of legal materials is carried out by means of a literature study, namely by conducting a review study of books, literatures, notes, and reports related to the problem being solved. Data analysis in this study uses qualitative data analysis, namely the process of organizing data according to emerging themes based on the research objectives (categorization) and then interpreting them. ${ }^{6}$

\section{Result and Discussion}

\subsection{Law Enforcement against Illegal Mining in Indonesia}

Indonesia is a country rich in natural resources, one of which is mineral resources which are mostly used as industrial raw materials. The Government of the Republic of Indonesia itself divides minerals into 3 groups, including: Group A minerals (strategic minerals), Group B minerals (vital minerals), group C minerals (non-strategic and non-vital minerals. This classification proves that there are so many mineral resources in Indonesia. ${ }^{7}$

Understanding the law in general is the whole of all the rules / regulations and rules in a life together, or can also be interpreted as a rule that regulates all human behavior that can be done and which should not be done or prohibited from doing in social life, where the implementing regulations are "can" be enforced with a sanction by the competent authority. ${ }^{8}$ Understanding law enforcement in general is an effort to realize legal ideas or concepts desired by the people, in the law enforcement process involves many things. Law enforcement can also be interpreted as: efforts to enforce or function in a real way legal norms as a guide for actors in traffic or legal relations in the life of society and the state. ${ }^{9}$

The enforcement of criminal law can be interpreted as the implementation of law by law enforcement officers and by everyone who has an interest in accordance with their respective authorities according to the rules of applicable law. The enforcement of criminal law is a system that involves the harmonization of values with the rules and real behavior of the community. These rules then

\footnotetext{
4Soejono Soekanto \& Sri Mamudji, 2004, Penelitian Hukum Normatif, Printing, Raja Grafindo Persada, Jakarta, p. 14.

5 Soerjono Soekanto, 1981, Pengantar Penelitian Hukum, UI Press, Jakarta, p.10

${ }^{6}$ Sri Hapsari Wijayanti, 2013, Bahasa Indonesia Penulisan \& Penyajian Karya Ilmiah, Raja Grafindo Persada, Jakarta, p. 222.

${ }^{7}$ Suroto and Gunarto, "Dampak Penambangan Pasir Besi Di Desa Bandungharjo, Banyumanis \& Ujungwatu Kabupaten Jepara Menurut UU No. 32 Tahun 2009 Tentang Perlindungan \& Pengelolaan Lingkungan Hidup", Jurnal Daulat Hukum Vol. 1. No. 1 March, 2018 url:http://jurnal.unissula.ac.id/index.php/RH/issue/view/247

8R.M. Gatot Soemartono, 1991, Mengenai Hukum Lingkungan Indonesia, Sinar Grafika, Jakarta, p. 23. ${ }^{9}$ Shant Dellyana, 2004, Konsep Penegakan Hukum, Liberty, Yogyakarta, p. 32
} 
become guidelines or benchmarks for behavior or actions that are considered appropriate or should be. ${ }^{10}$

Law enforcement includes preventive and repressive law enforcement. Enforcement of environmental law is an effort to achieve compliance with regulations and requirements in applicable legal provisions in general, individually, through supervision and application of administrative, criminal and civil sanctions.9 Enforcement of environmental law is also closely related to the ability of the apparatus and public compliance with applicable regulations.

Preventive efforts are carried out with outreach activities to the community at the Polres and Polsek levels, while repressive efforts are carried out through a series of investigative actions. There are several obstacles in the law enforcement process, namely the presence of irresponsible individuals, limited facilities and infrastructure and a lack of legal awareness from the community. ${ }^{11}$

Legal rules in mining are divided into two types, written and unwritten mining law rules. Written mining law is the legal rules contained in legislation, treaties, and jurisprudence. Unwritten mining laws are legal provisions that develop in society. The form is unwritten and local in nature, meaning that it only applies to the local community. ${ }^{12}$

Preventive environmental law enforcement can take the form of dialogue, discussion, counseling and monitoring. More broadly, preventive environmental law enforcement leads to supervision carried out by the competent authorities. In this case, the supervision lies with the official issuing the business license in the mining sector in accordance with their authority.

Consistent and integrated law enforcement will also bring benefits to the community, namely the emergence of a deterrent effect, so that it can prevent someone who wants to commit corruption. Another benefit is the growth of public trust in law enforcement efforts and law enforcement officials, so that public support for law enforcement agencies will be strengthened. On the other hand, if there is inconsistency and incoherence in law enforcement, the public will judge that in the law enforcement process there is a tug of war between interests, so that trust in law enforcement will weaken. ${ }^{13}$

Article 71 of Act No. 32 of 2009 concerning Environmental Protection and Management (UUPPLH) states that:

(1) The Minister, governor or regent/mayor in accordance with their respective authorities are obliged to supervise the compliance of the person in charge

\footnotetext{
${ }^{10}$ Barda Nawawi Arief, 1991, Upaya Non Penal Dalam Kebijakan Penanggulangan Kejahatan, Semarang: Makalah Seminar Kriminologi UI. 1991, Hukum Undip, p. 42.

11 Keris Aji Wibisono and Umar Ma'ruf, "The Law Enforcement Against The Crime Of Illegal Mining", Law Development Journal Vol $3, \quad$ No 2 (2021), url: http://jurnal.unissula.ac.id/index.php/ldj/article/view/16210

${ }^{12}$ Arif Kristiawan, Sri Endah Wahyuningsih and Rakhmat Bowo Suharto, "Perspektif Tindak Pidana Administrasi Terhadap Tindak Pidana Pertambangan Tanpa Ijin (Peti) Dalam Undang-Undang Nomor 4 Tahun 2009 Tentang Mineral \& Batubara", Jurnal Daulat Hukum Vol. 1. No. 1 March 2018 ISSN: 2614-560, url: http://jurnal.unissula.ac.id/index.php/RH/issue/view/247

${ }^{13}$ Achmad Budi Waskito, "Implementasi Sistem Peradilan Pidana Dalam Perspektif Integrasi", Jurnal Daulat Hukum Vol. 1. No. 1 March 2018 ISSN: 2614-560X, url: http://jurnal.unissula.ac.id/index.php/RH/article/view/2648/1992
} 
of the business and/or activity with the provisions stipulated in the laws and regulations in the field of environmental protection and management.

(2) The minister, governor, or regent/mayor may delegate their authority in supervising the official/technical agency responsible for environmental protection and management.

(3) In carrying out supervision, the Minister, governor, or regent/mayor shall stipulate an environmental supervisor who is a functional official.

Based on Article 71 of the UUPPLH it can be explained that government officials and Regional Governments are in accordance with the field of environmental protection and management and have the authority and obligation to carry out supervision in order to guarantee and ensure that those in charge of businesses and or activities have complied with the applicable laws and regulations. The Government and Regional Governments may also appoint environmental supervisory officers. Article 73 of the UUPPLH stipulates that "The Minister can supervise the obedience of the person in charge of the business and/or activity whose environmental permit is issued by the regional government if the Government considers that a serious violation has occurred in the field of environmental protection and management".

Based on Article 73 of the UUPLH, it can be explained that the law gives the government the broadest authority to supervise environmental permits in the area if serious violations have occurred. Violation in this case is a violation of the law that results in pollution and/or environmental damage that is relatively large and causes unrest in the community. If a serious environmental violation occurs and requires more handling, then the Government has the authority to take certain legal actions so that the pollution and/or destruction carried out by the person in charge of the business and/or activity does not spread and can be handled immediately.

Illegal mining destroys the environment and ecosystems that have already been formed, so that degradation and deforestation occur in all regions. The biggest contributor to environmental damage is the existence of illegal mining, illegal mining destroys the environment Mining must take into account the benefit, not just the consideration of retribution.

Law enforcement in a broad sense in the mining sector includes administrative law enforcement, civil law enforcement, and criminal law enforcement. Act No. 4 of 2009, in addition to strictly regulating perpetrators of criminal acts in the mining sector, also strictly regulates officials who issue permits in the mining sector, all of which can be categorized as illegal mining.

Articles that regulate illegal mining in Act No. 4 of 2009, starting with Article 158, Article 1608 paragraphs (1) and (2), Article 161, Article 163, and Article 164. Handling events or cases related to illegal mining, showing efforts to take action against crimes in the field of illegal mining by using a criminal policy (penal policy). ${ }^{14}$

\footnotetext{
${ }^{14}$ Barda Nawawi Arief, 2001, Masalah Penegakan Hukum \& Kebijakan Penanggulangan Kejahatan, Citra Aditya Bakti, Bandung, p. 73.
} 
Administrative law enforcement in illegal mining is carried out preventively, in this case more emphasis is placed on monitoring and controlling an activity or action. Supervision in law enforcement of mining administration in a limited manner has been regulated as stipulated in the provisions of Article 39, Article 78 and Article 79 concerning Mining Business Permits (IUP) or Special Mining Business Permits (IUPK). The signs contained in the Mining Business Permit (IUP) or Special Mining Business Permit (IUPK), are obligations that must be carried out by the recipient of the Mining Business Permit (IUP) or Special Mining Business Permit (IUPK), and if a violation is committed, the official who issuing the permit has the right to impose sanctions. ${ }^{15}$

Based on Article 151 paragraph (2) of Act No. 4 of 2009 sanctions are in the form of written warnings, temporary suspension of part or all of exploration activities or production operations, and/or revocation of IUP, IPR and IUPK. Enforcement of civil law in illegal mining is an unlawful act, as stipulated in Article 1365 of the Civil Code, which states "Every act that violates the law, which causes harm to another person, obliges the person who because of his fault in publishing the loss to compensate". In terms of environmental law, due to environmental pollution and environmental destruction, this is the basis for a lawsuit in environmental disputes.

\section{Clossing}

The process of law enforcement against mining activities that take place without a permit in accordance with the provisions stipulated in Act No. 4 of 2009 can be carried out through 3 (three) legal areas, namely administrative law enforcement, civil law enforcement, and criminal law enforcement. In the future, it is hoped that there will be coordination and integration between related agencies, especially to carry out socialization activities for legal counseling regarding Act No. 4 of 2009.

\section{References}

\section{Journals}

[1] Achmad Budi Waskito, "Implementasi Sistem Peradilan Pidana Dalam Perspektif Integrasi”, Jurnal Daulat Hukum Vol. 1. No. 1 March 2018 ISSN: 2614-560X, url: http://jurnal.unissula.ac.id/index.php/RH/article/view/2648/1992

[2] Arif Kristiawan, Sri Endah Wahyuningsih and Rakhmat Bowo Suharto, "Perspektif Tindak Pidana Administrasi Terhadap Tindak Pidana Pertambangan Tanpa Ijin (Peti) Dalam Undang-Undang Nomor 4 Tahun 2009 Tentang Mineral \& Batubara", Jurnal Daulat Hukum Vol. 1. No. 1 March 2018 ISSN: 2614-560,

url: http://jurnal.unissula.ac.id/index.php/RH/issue/view/247

[3] Dany Andhika Karya Gita, Amin Purnawan and Djauhari, "Kewenangan Kepolisian Dalam Menangani Tindak Pidana Pertambangan (Ilegal Mining)

${ }^{15}$ Salim HS, 2014, Hukum Pertambangan di Indonesia, Rajawali Pers, Jakarta, p. 266-268. 
Menurut Undang-Undang Nomor 4 Tahun 2009 (Studi Di Kepolisian Negara Indonesia)", Jurnal Daulat Hukum Vol. 1. No. 1 March 2018 ISSN: 2614-560X, url: http://jurnal.unissula.ac.id/index.php/RH/issue/view/247

[4] Keris Aji Wibisono and Umar Ma'ruf, "The Law Enforcement Against The Crime Of Illegal Mining", Law Development Journal Vol 3, No 2 (2021), url: http://jurnal.unissula.ac.id/index.php/ldj/article/view/16210

[5] Suroto and Gunarto, "Dampak Penambangan Pasir Besi Di Desa Bandungharjo, Banyumanis \& Ujungwatu Kabupaten Jepara Menurut UU No. 32 Tahun 2009 Tentang Perlindungan \& Pengelolaan Lingkungan Hidup", Jurnal Daulat Hukum Vol. 1. No. 1 March 2018 url: http://jurnal.unissula.ac.id/index.php/RH/issue/view/247

\section{Books}

[1] Abrar Saleng, 2004, Hukum Pertambangan, UII Press, Yogyakarta

[2] Barda Nawawi Arief, 2001, Masalah Penegakan Hukum \& Kebijakan Penanggulangan Kejahatan, Citra Aditya Bakti, Bandung

[3] Gatot Supramono, 2012, Hukum Pertambangan Mineral \& Batu Bara di Indonesia, Rineka Cipta, Jakarta

[4] Ruth Laksmi Charisma, Problematika Penegakan Hukum Kegiatan Pertambangan Batuan Ilegal di Kota Samarinda, Jurnal Hukum, Faculty of Law Universitas Mulawarman

[5] Salim HS, 2014, Hukum Pertambangan di Indonesia, Rajawali Pers, Jakarta

[6] Shant Dellyana, 2004, Konsep Penegakan Hukum, Liberty, Yogyakarta

[7] Siti Sundari Rangkuti, 2008, Perangkat Hukum Lingkungan: Dari Ius Constitutum, Sekali Lagi, Ke Ius Constituendum, disampaikan pada Seminar "Good Governance and Good Environmental Governance", Faculty of Law Universitas Airlangga, Surabaya

[8] Soejono Soekanto \& Sri Mamudji, 2004, Penelitian Hukum Normatif, Cetakan Kedelapan, Raja Grafindo Persada, Jakarta

[9] Sri Hapsari Wijayanti, 2013, Bahasa Indonesia Penulisan \& Penyajian Karya Ilmiah, Raja Grafindo Persada, Jakarta 